\title{
War, Population Growth, Inequality, and the History of the World State Idea: The Causes of World Wars and Global Governance Evolution over the Long Duree
}

\author{
Anna Cornelia Beyer \\ Department of Politics, University of Hull, Hull, UK \\ Email address: \\ c.beyer@hull.ac.uk \\ To cite this article: \\ Anna Cornelia Beyer. War, Population Growth, Inequality, and the History of the World State Idea: The Causes of World Wars and Global \\ Governance Evolution over the Long Duree. Humanities and Social Sciences. Vol. 6, No. 5, 2018, pp. 159-172. \\ doi: $10.11648 /$ j.hss.20180605.14
}

Received: October 10, 2018; Accepted: November 2, 2018; Published: November 30, 2018

\begin{abstract}
Humanity has experienced three major periods of war - 500Bc the Greek wars, 1600AD the Thirty Years War and 1900AD the Two World Wars. These were the most significant times of war in human history, as far as is known to Western science. IR scientists do not know much about other regions in the world. All of these major periods of war brought forth the classics in the field of IR (International Relations) and the main political inventions, for example Hobbes with the principle of sovereignty, or Kant with the ideas for global democratic organisation, or the invention of the discipline of IR and the UN. All of these periods of war have been preceded by sudden massive population growth. This article will sketch the evolution of war and politics over the longue duree. For this purpose, the history of war and the history of political thought will be discussed. As causes for the major wars, sudden massive population growth is identified. How the latter causes war is theorised in the paper, as far as possible. Population is still massively growing in the times of the $21^{\text {st }}$ century, and should be kept in reasonable limits. Arguments for protection of childlessness will be presented at the end of this article.
\end{abstract}

Keywords: Major War, Causes, International Relations Theory, Population Growth

\section{Introduction}

We have experienced in the known history of 'Western civilization' three major periods of war: $500 \mathrm{BC}$ the Greek wars [1], 1600AD the 30 Years War and following troubles, 1900AD two global wars, the Two World Wars. While Western science doesn't know enough about wars in the missing periods or other regions - it is certain that crusades occurred, that Central America and Asia experienced wars in the meantime, but not sufficient about these occurrences is known to Western International Relations scholars and must therefore here be excluded - these three periods of war produced all the to us currently available and popular literature on politics and related matters that Western science uses: The Greek philosophers that scientists refer to wrote in the first period of war, IR's 'classics' - Hobbes, Locke, Kant etc. - wrote in the second period or shortly after, and the discipline of International Relations (IR) itself was established within the third period of war around 1919.
While this in itself is a novel insight, an additional factor that explains the potential causes leading to these major periods of war that have not yet been sufficiently discussed in the literature on war causation will be presented here: Sudden massive population growth. As the data in the appendix illustrate, all three major periods of war have been preceded by unprecedented massive population growth. This factor in itself is not completely unknown in the IR literature: World System [2] theorists talked about lateral pressures to mean the same in their critique on capitalism and hegemony [3], but they did not look back as far in history, usually stopping around 1400 and did not necessarily draw a connection to war. Interestingly, however, taking this factor seriously and looking at the - admittedly very sparse - available historical data shows us that all three major periods of war have been preceded by sudden massive population growth. The same as far as it is possible to tell - happened in China where the main period of war was in the 18th century [4].

Principally, this explanation is not illogical. Rapid massive 
population growth must put strain on both political and economic systems, which might cause them to collapse or dysfunction, leading to massive poverty, inequality and governance failures, all known causes of violence that scientists also observe in many developing regions of the world today or in the recent past. For example, a similar mechanism could be speculatively put on the cause of the Arab Spring: A 'youth bulge' developed after massive population growth in the 1990ies, met with unemployment in the 2000s, and this created the favourable conditions for terrorism and rebellions.

Little is known in the literature that can guide us further here. The reasons for these periods of sudden massive population growth can only be speculated about, and might have to do with civilizational progress, for example due to inventions, which might have brought about an easier life for many, economic progress, and hence population growth. But this must remain speculation, as the information is not available. What scientists can know is that before all major periods of war, important armaments inventions - the crossbow around $400 \mathrm{BC}$, the rifle around $1600 \mathrm{AD}$, the tank around 1900AD - were made, which indicates that probably other inventions also flourished around these times, supporting the above interpretation.

This article will propose a model of political evolution first - all the major IR writings throughout history have produced important political changes and inventions which attempted to secure the peace for some time to come, and will then present the explanation, including all what scientists have of evidence in the appendix, for the model of major war causation. The main part will also include a treatise on feminism with the defense of the decision to abstain from procreation, an interest that concerned at least some women throughout history and is met with not sufficient rights and protection in many places around the world.

\section{The Model: Sudden Massive Population Growth, Inequality, Major War, and World State Ideas}

All major ideas for new political inventions (the city state, the Roman Empire, the sovereign state, the UN system) have been made in the three major periods of war in human history (the Greek wars, the Renaissance period/ 30 Years war, the Two World Wars). All of these times of major upheaval in the whole of human history brought forth the known world state ideas that scientists teach (sovereignty, UN, EU etc.). Of course, also most writing about war was produced in these times (Thucydides, Hobbes, whatnot). Humanity could still be in one of those periods (the third period so far). These periods have been causally connected to sudden massive global or at least regional (in the Greek period) population increases (there is some data available on population growth that goes that far back, but not much). So, in all of these periods, probably technological inventions brought about an easier life, this resulted in sudden massive population growth, and then inequalities and poverty and struggles for equality (power, status etc.) resulted in the known causes of war. For example, industrialization could be one such 'technological' change which brought about the Two World Wars, with first increases in life chances for some, population growth, and many groups, classes and whatnot left out. That's the basic model. Now, the predictions go that the world is still in a period where dramatic population growth for until 2090 is predicted (some say up to a total of 14 billion by 2090, others are a bit less dramatic, but overall the picture is not very reassuring). This could on the one hand mean opportunities. For example, it is possible that economic development in Africa is dependent on population growth, as one needs manpower for a functioning economy (compare London, Japan and New York vs Russia, for example, to see that). On the other hand, if it is not well managed and supported, it might mean a risk for continued severe conflicts, as has just happened in Syria, with mass migrations etc. Hence, looking at history, humanity might need to learn that to respond to this a larger, stronger and much more efficient international or global governance system that can help distribute resources to where they are needed is required.

\section{History of War in Graphs}

Interpretation: The Greek wars are shown in the first red circle around 500BC. Interestingly, and still without any explanation, is the apparently relative lack of war around 100 to $200 \mathrm{AD}$ (second red circle).

Explanation: As far as the data are known, relatively few wars of relatively minor importance occurred after 0AD and before the 30 Years War in 1618. Exceptions are, for example, the crusades. But all available data indicate that wars at least in Europe in this period were still of less significance than after $1600 \mathrm{AD}$. The reason for this is unknown. Along with this, few political treatises were produced in this period, which was more marked by the dominance of religion in international affairs.

Table 1. Own production. Major periods of war and political theory classics.

\begin{tabular}{lll}
\hline Year & Event & Writers \\
\hline 500BC & Greek wars (Greece against Sparta etc.), see figure 1 above. & Thucydides (500BC), Plato (500BC), Aristotle (400BC) \\
1600AD & $\begin{array}{l}\text { 30 Years War and following troubles (1618-1648, early 17th } \\
\text { century), following troubles see figure 2 above. }\end{array}$ & $\begin{array}{l}\text { Thomas Hobbes and John Locke (early 17th century) } \\
\text { Immanuel Kant and Jean-Jacques Rousseau (early 18th century) }\end{array}$ \\
1900AD & World War I and World War II, see figure 2 above. & $\begin{array}{l}\text { Establishment of the discipline of International Relations in 1919 with all } \\
\text { the following publications. }\end{array}$ \\
\hline
\end{tabular}



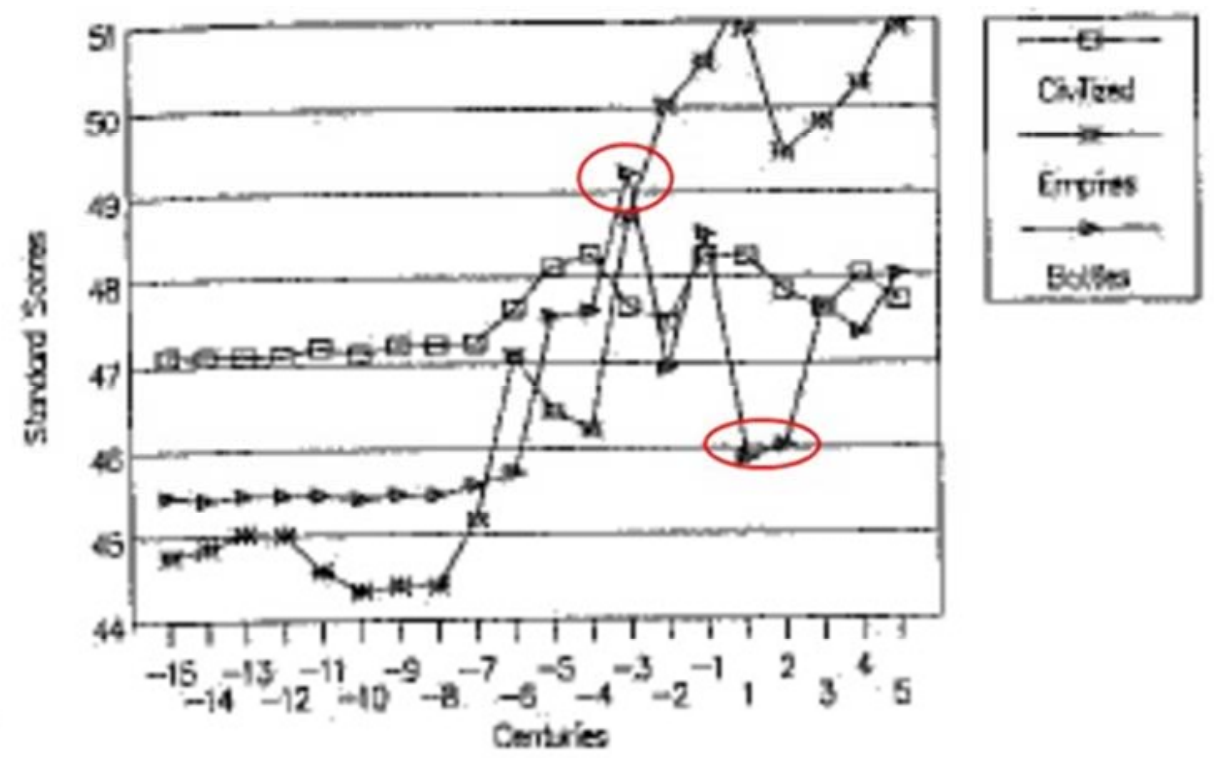

Notes to Figure 3.2: See be Notes to Figure 2.1. Most of the dasio sases remained below the xwerge standerd seote of 30 , except. for the sum of imperial sixes, which did not jet veatb

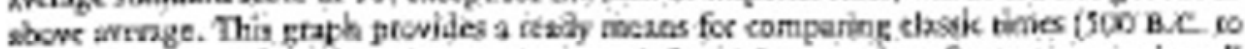

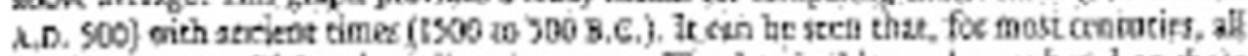

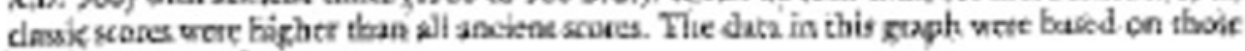
in Tables 3.2 and 3.3 .

Figure 1. Civilizations, Empires and Wars, 1500 BC to AD 500. Source: William Edward (1992): Civilizations, Empires and Wars. A Quantitative History. Jefferson: McFarland \& Co, 55.

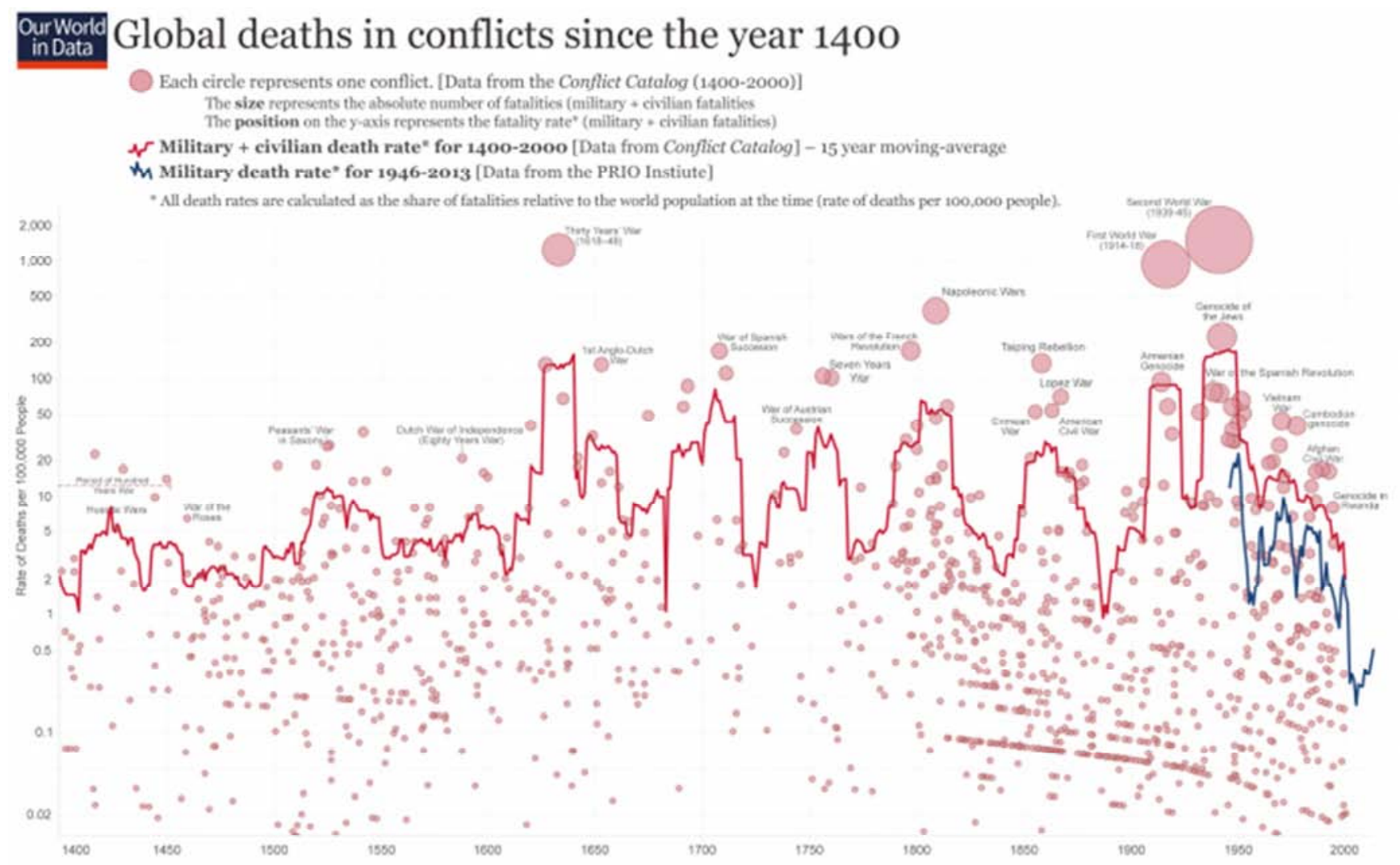

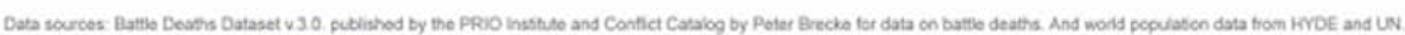

Figure 2. Source: Max Roser: War and Peace. Online: https://ourworldindata.org/war-and-peace. Republished with kind permission. 
Explanation: All the main writings on politics and international relations that IR scientists commonly refer to today have been produced in or after the known three major periods of war. IR scientists do know less about wars and political writings in and from other regions of the world, such as in particular the Middle East and Asia, where history might have produced different results. Other regions of the world might in the past not have had the level of development to produce major political writings, even if wars might have occurred, such as for example in South and Central America.

\section{World State Ideas}

That ideas have been, are and will be at the root of societal and hence political evolution has been maintained especially by Constructivists:

"Epistemologically and methodologically, whereas realism is mostly a materialism approach and can thus somewhat afford to ignore the real processes of ideational change and the transformational power of ideas in human society, constructivism, as an ideationalism approach, cannot afford to ignore the real processes of ideational change while preaching the transformational power of ideas. In order to have much a say on ideational change at all, constructivism needs to look at real processes of ideational change at the individual, state-level, and inter-state level" [5]

Tang maintains that "consistent with the social evolutionary approach toward institutional change, this process of institutionalizing regional peace [here referring to global institutionalisation] has often been led by power and ideas that promote peace, rather than either ideas or brutal power alone." [6].

Looking at the past, ideas had a massive transformative power on world politics: All the major writings on war, as well as the writings on political solutions have been made in the above stated three periods of major warfare. There is nothing - or not much - from other periods, such as the early years after Christ, for example. There was maybe a lot of stability then, with existing political institutions working fairly well, no major war and no massive changes, which could account for this fact.

\subsection{Early Thoughts}

The period of the Greek wars, if or if not really one of the first major periods of war, seems to have inspired much political thought and invention, from the first forms of democracy, to the city state, to the formation of the first leagues, to - arguably - the Roman empire etc.

However, as Malchow maintains, apart from Thucydides, whom Malchow calls 'the father of IR', most contemporaries did not concern themselves with interstate affairs: "Ancient Greek literature has little to say about the state system and interstate relations, and can offer little direct contribution to the construction of IR theory" [7]. However, Thucydides, writing around $500 \mathrm{BC}$, the time of the Persian Wars (500448BC), established as the first author a history of war, an analysis of causes of war, principles of balance of power, hegemony, and Realpolitik, and hence, arguably, the school of 'Realism'.

Zarnett quotes Thucydides:

"Indeed this [war] was the greatest movement yet known in history, not only of Hellenes, but of a large part of the barbarian world-I had almost said of mankind. For though the events of remote antiquity, and even those that more immediately precede the war, could not from lapse of time be clearly ascertained, yet the evidences which an inquiry carried as far back as was practicable lead me to trust, all point to the conclusion that there was nothing on a greater scale, either in war or in other matters." [8]

If this is taken at face value, it would mean the Greek wars against Sparta etc. were the worst wars in the history of mankind up to then. In fact, in IR, Thucydides is usually taken as the starting point and little if any discussion occurs or knowledge is collected about wars preceding these wars.

Hammond collected political writings on 'world state ideas' and political inventions from precisely this era and writes about the thought of Plato and his contemporaries. The sole references for the purposes here to be gathered from these writings could be an analysis of evolution of society from primitive times towards 'civilised' societies and the description of the first forms of institutions or alliances: "In primitive times, the most elementary form of society, the family, lived simply off natural products. As families grew and the different branches continued to cohere, the need for mutual support and protection necessitated more organization." [9] and: "They had a Hellenistic League and several other leagues, in which citizens (men, not women or slaves) from different cities enjoyed citizenship".

\subsection{Renaissance}

The Renaissance period, starting in Italy in the $14^{\text {th }}$ century and spreading throughout Europe until the start of the modern period, around 1750, brought forth major war - the 30 Years War, 1618 to 1648 - as well as a substantial body of writings about war and politics and peace. For example, some of the best known writers from this period count amongst the classics in IR literature: Abbe St. Pierre, Hobbes, Rousseau, Kant (Macchiavelli was the only of the classics living and writing shortly before the outbreak of the 30 Years War). One can argue that their ideas have been developed in response to major war, in particular the 30 Years War. All of these thinkers dealt with either the problem of war and/or its solutions. The ideas for solutions differ, from arguments for the creation of sovereignty (Hobbes), to arguments about global integration for peace (Kant, St. Pierre), to liberal ideas about freedom (Rousseau).

Hobbes, as the historically first contributor, described how a functioning state would need to be structured to prevent or solve the problem of civil war. His ideas arguably contributed to the establishment of the principle of sovereignty laid down and realised with the Treaty of Westphalia. [10]

Kant, later than Hobbes, and a follower of St. Pierre argued for a confederation of republics. [11] While this idea 
at the time seems not have to been taken up, it later became extremely influential for the creation of the United Nations and the ideology to spread democracy around the globe. It also influenced research on the Democratic Peace Theory, which by some is believed to be the most successful research programme in the field of International Relations. Previous to this, the ideas of Kant might have served to inspire the creation of coalitions of republics, such as the Concert of Europe, or the League of Nations.

Rousseau is generally believed to have influenced Liberalism more. [12]

\subsection{Modern Period}

The modern period was marked by two major wars, the First and Second World War. These two major wars inspired new solutions to the problem of war, similar to the 30 Years War previously. While the First World War was responded to with the creation of the League of Nations, the latter was not sufficiently strong and developed enough to prevent the Second World War. After WWII, the League was abolished and replaced with an even stronger organisation along similar ideas, the United Nations and the UN's sub-organisations. Also, additional institutions were established, such as the European Union, NATO, as well following this many others. This period was also marked by a strong international movement supporting the creation of a world state.

The period directly following the Second World War for many decades was marked by the Cold War, in which two opposing superpowers and their alliances found themselves in a standoff, including arms races, intellectual and technological races and ideological wars for supremacy. In this period, on the Western side international institutions were further developed and spread. On the Soviet side, also ideas for how to establish global or international peace were developed.

When the Cold War ended, the term 'global governance' became fashionable. It referred to the collection of attempts to govern on a global level, from top to bottom, including the UN system, other forms of cooperation between countries, and activities at and from the local level.

More recently, the global governance debate is not as prominent anymore, but still of substantial value. The era of the 'Global War on Terrorism' (roughly 2001 to 2008 or 2015) brought forth new literatures about war (in particular about how to counter terrorism) but also inspired new efforts to think about international or global peace. The world state discussion was revived, based on the named classical literatures, and some prominent new writings.

Ideas for reform of the current global governance system were also presented in this period.

\section{Causes of War}

Oftentimes wars center around three main causal factors: fear (also theorized as uncertainty or insecurity, the Security Dilemma etc.), honour (also theorized as prestige, status, recognition etc.) and interests (usually understood in a quite material sense, as capabilities, military, economic or other elements of power, such as GDP, population strength, economic dominance, technological development, military strength, which is dependent on economic dominance etc.). In systemic theory, as well as in world systems theory, the causes of war are usually described in terms of power struggles, transitions, balances and so forth. Polarity - the distribution of material capabilities, such as economic strength, military might, population base, technological advancement, and political stability (the latter not strictly a material factor) - is usually taken to describe the constellation of the system and from there on estimate the various risks of war. Different constellations of polarity unipolarity, multipolarity, bipolarity, or one, two or many great powers - are thought to bring forth different risks of war $[13,14,15]$. Unipolarity is thought to lead to many frequent small wars, but no major wars. Multipolarity is thought to have the risk of not too frequent but major wars. Bipolarity is generally thought to be most stable, but if it is thought as cluster bipolarity (meaning a constellation in which two opposing alliances dominate) it is thought to possibly bring forth world wars [16]. In general, however, these constellations all are centered around counting material strength, counting any material factors that can either be utilized for war or are necessary for survival. These factors all exclude soft factors, such as ideology, culture, knowledge, religion, law, norms etc. World systems theory likewise looks mainly at material factors, but focuses more on a critique of domination in the international system, i.e. hegemony, what it is based on, i.e. capitalism, and when it changes hands, i.e. hegemonic transition. Overall, however, all presented approaches to explain the causes of war on a global systemic level take material factors very seriously. Exceptions do exist, such as for example Samuel Huntington's Clash of Civilisations [17] theory, in which religion and culture as a cause for conflicts are promoted. But generally speaking it seems that material factors are thought more important for war than immaterial factors. If this is always true or not needs to be decided somewhere else. However, the argument here is that hence - taken the knowledge about causes of war together - unequal distributions of material capabilities usually bring forth conflicts. This is not a necessary result, some inequalities remain stable, but it is a normal and common cause.

To give some examples: Terrorism, even if one follows Huntington, can be causally related to a large degree to material inequalities [18]. This has by now confirmed in a number of studies and is even hinted at in Huntington. Classical literatures on terrorism conceptualise this with concepts such as 'life chances', imperialism and 'structural violence', for example, which to a large degree mean that material power differentials exist which are causally related to aggression and violence [19]. Similarly, for both World Wars, power differentials can be brought in to propose some major causes, such as the 'backwardness' of the Balkan countries before the First World War, as well as 
maybe the lack of colonies for some European countries, and the Great Depression with resulting mass unemployment for the Second World War. The Cold War is here an interesting case a bit out of the order. Apparently, this conflict was marked by higher levels of equality between the two contenders. Equality was not strict, complete or consistently present, but it was higher than before the Two World Wars or in many other cases of conflict. Potentially, here is a reason for the assumed stability of this system to be found. When equality collapsed due to overspending of the Soviet Union and economic decline, the conflict ended. Of course, in all wars also ideological factors play a prominent role. This occurred in both World Wars as well as in the Cold War. However, the main theories of causes of war focus on material factors as causal explanations and dismiss ideology as a possible sole cause (or at least do not theorise it in this way).

For Realism, this assumption goes back to the early writings about war, from Thucydides to others, where struggles for power, balances of power, etc. were thought about. Power, and the struggle for power as a cause for conflict, have since then become the main idea that the broad school of Realist thought bases their explanations for war and/or politics in general on.

Hence, if it is assumed that material factors are causal for war and conflict, it is clear how the previously mentioned occurrences - sudden massive population growth in certain historical phases - could lead to war. Population growth, due to new inventions of technologies and an easier life at least for some at least for some time, might result in relative overpopulation when the first boom has receded, which will bring forth distributive pressures, hence relative inequality and poverty for many. These, on the other hand, are known causes of civil wars, terrorism, and revolutions, which can as well easily lead to major war (the First World War was sparked by terrorism, the Second by, one could say, a revolt). Even if this does not occur, struggles about distribution of the spoils of the 'new economy' might likely occur and can result in conflict and possibly major war if these pressures are growing too massively and cannot be managed. At the same time, sudden massive population growth might put existing political systems under pressure. Elites and institutions might not be able to cope with their distributive functions if populations suddenly increase by $100 \%$ or other similar dramatic numbers. Existing political structures might fail, something IR scientists call today 'failed states' when it happens in developing countries, and that is known to be causally related to civil wars.

\section{Population Growth Causes and Effects}

Population growth might result out of technological inventions which increase economic output and hence improve living conditions.

While, as discussed above, sudden massive population growth, if unchecked and unmanaged, might produce governance failures and wars. As one of the few who link population growth to conflict, Penrose writes about Japanese territorial expansion into China to make the point and continues: "Some population writers have predicted a situation in which a slow, steady deterioration of economic conditions in certain areas over a long period of time, due to overpopulation, will lead to desperate attempts at external expansion by war. ... Population factors therefore appear in some areas to have accentuated the social and political consequences of the business cycle." [20] Conflict might follow due to the established problem of potential unemployment crises following massive population growth [21], hence inequality and poverty for some or many after a period of growth. However, the population growth possibly causal for the three periods of major war in history seems in a degree that is at each point in time unprecendented in then previous history (see appendix, relevant data marked).

On the other hand, population growth can also be needed to fuel a strong economy. For example, in sparsely populated countries or regions, one could think of rural areas in Russia or Africa for example, economic capacity is naturally not as strong as in densely population areas or regions, such as city states, Japan, London, New York, etc. Hence, population growth might be needed for economic growth and might at times be promoted by the political establishments. However, if unchecked, this might result in the above problems.

To give an illustration of results of massive, sustained population growth, the example of China shall be cited here: "One the one hand, rising population and population density initially led to intensified production, heightened commercialization, and greater urbanization in the eighteenth century. On the other hand, sustained population growth eventually culminated in the inevitable decline of per capita production and subsequent emiseration in the nineteenth and twentieth centuries. The process was Boserupian on the upswing, Malthusian on the downswing" [22].

Population growth in itself is often caused by technological, scientific and hence economic progress, but the latter leads later to fertility decline:

"First, the permissive basis for the great rise in per capita product, combined with high rates of population growth, was the rapid increase in our tested knowledge of natural processes, applied to problems of production technology [meaning industrialization]. ... [this means] pressure towards higher production levels. ... It also has bearing on fertility." [23]

Generally, the relationship between population growth and development economics is not clearly defined, various theories propose different mechanisms connecting these two. [24] However, if population growth is met with lacking investment and economic growth, a natural outcome is underemployment and poverty, and this leads to the known causes of conflict.

For example, significant population growth has been promoted in Muslim countries in particular in the 1990ies. 
This is mentioned in Huntington's thesis and explained as culturally dependent. Some analysts relate the resulting 'youth bulge' with accompanying massive youth unemployment to the Arab Spring and possibly the rise of Islamist terrorism. In addition, in the current phase, it seems that propaganda moves to increase population growth in some Eastern European countries and Russia, but also in some Islamic countries, such as Turkey, are taken. Again, this can result in the wanted effects of economic growth if the economic conditions are favourable and it is well managed. If economic downturns occur and if the growth exceeds the manageable limit, there is an intense risk of conflict. In the current period of global development, it would make sense to use the United Nations to monitor population growth and develop recommendations as well as support mechanisms in particular economic support mechanisms, such as for example, but not only, a Global Welfare State or a Global Marshall Plan, in addition to already known economic processes, such as globalization etc., or mechanisms that are currently in discussion, such as a General Basic Income. On the other hand, it also would be sensible to promote and ensure women's rights to govern their reproductive capacities in a self-determined way, with the necessary rights and tools available.

\section{In Defense of Childlessness}

Out of the Generation X (the generation born between 1965 and 1977 roughly), it was stated that about $40 \%$ of women (now in their 40ies) remained childless [25]. The reasons have not yet been established. Overall, in the total population of today, 1 out of 5 women remains childless. This should not be a cause for public outcry and moralisation, but rather a point of joy and a sign that society is advancing and women's rights are improving.

Historically, before the invention of contraception and other family planning methods, having children was the common fate for most women, apart from nuns and infertile women. This fate might have been often accepted as unavoidable, but in the literature there is historical evidence that at least some women suffered under it. For example, Florence Nightingale seems to have spent a life trying to avoid the fate of being married and having to have children. In fact, it is likely that the struggle against this fate caused immense creativity and was also influenced by it. Other examples are women who pretended to be men and joined foreign armies as doctors or started to study at universities, disguised as men. How many women would have liked to do so and to avoid pregnancy is unknown, but the success of family planning methods in reducing reproduction rates indicates that it is by far not every woman's wish to become a mother.

From a woman's point of view, this decision or point of view makes sense. Children pose a responsibility (even though of course also a source of joy) that is virtually unmatched by any other possible responsibility, maybe apart from the one of having to care for elderly parents or suffering from a debilitating disease. Such responsibility does restrict the possibilities of enjoying all the other options that life in today's society has to offer, a society in which women have far more chances than ever before, even if they are by far not yet really equal, even in the most advanced countries. Historically, the childbearing function of women was THE most important cause of gender differences in academic achievement, professional and political participation and so forth, and was at the root of all the restrictions and limitations that women experienced. In many more traditional societies this still applies.

Alongside 'the pill', the inventions of the modern welfare state with affordable child-caring services brought some improvements for many women who now can afford to return to work, at least part time, after having cared at home for their children in the first years of life. But still statistics calculate that women work on average 14 hours per week more than men if one includes the housework and the care for children, and this must of course be considered a reason for women in general still not catching up to be equal with men in the public sphere.

This article will first present some general arguments for voluntary childlessness from a woman's point of view.

It will then conclude with an argument that the rights of childless women should be protected against pressures to become a mother and against stigma of remaining childless.

\section{Arguments for Childlessness Today}

Overpopulation worldwide: The world is assumed to host 7 billion people today. Some projections predict double this number - 14 billion! - by 2090 [26]. In many countries, growing population or overpopulation causes a serious strain on the economy, in particular when people get older. The youth bulge [27], on the other hand, in the Middle East, turns critical when it meets a weak economy and mass unemployment. These factors meeting together are thought by some to be at least partially responsible for phenomena such as the Arab Spring and Islamist terrorism. China, for example, has implemented a policy of restricted reproduction ('One child policy') to avoid the fate of India and to allow for stable growth and an increase of wealth in their already massive population. In the Western world, reproduction rates are by far not as high, and in some places a decrease in population is even expected. However, pressures of immigration, in particular by young individuals from developing countries, are a possibility to redress this decrease. It has long been warned by the United Nations and other organisations that in particular an unrestricted growth in the world population could have devastating consequences for humanity's survival, as it would impact the economy, the environment, etc. More people mean more need for jobs, but also mean more cars, more water used, more farms needed, more mega-cities being built. It is by far not clear how many people the world will be able to hold without destroying the very basis for humanity's own survival. Until humanity has not developed a significant 
capacity to inhabit outer space and foreign planets, it therefore makes sense, even though it is not an imperative for everyone, from an informed cosmopolitan point of view to decide against children.

Costs of having children: A second point is a traditional one that, however, seems to affect many women today and might affect many, or potentially even more, women in the future. The costs of education, housing and childcare are rising in many places. For many women this means that children are simply financially out of reach, in particular in their childbearing years when the earning capacity is for many not as strong as maybe later in their careers. It will be interesting to see what the generation of today's students in the West, many of whom will leave university with a significant debt that at other times could have been used to purchase a house, will decide in terms of their own reproduction. It is very much possible (but this is speculation) that this generation will reproduce in even smaller numbers than the current generation of 40 year olds.

Freedom is maintained without children (time for reading, time to work, less burnout and stress and mental illness, time and money to travel, etc. etc.): Freedom has become ever more available for women with increasing rights of access. Women therefore learn increasingly to cherish the freedoms that traditionally only a select few, and mostly men, enjoyed. Time that a mother has to spend on raising children can be used by childless women for any purpose imaginable, from investing in professional success, to exploring the arts, and so on and on. Liberating women from the childbearing role allows for the growth of creativity in a significant section of the population (childlessness is more a phenomenon in the Western and developed world still). Humanity can only imagine what products this freed creativity will bring over time!

All big things have been achieved mainly by women without children (look at the Western female leaders, Merkel and May, both childless) or by men without children (many of the great thinkers either stayed unmarried and childless Kant, Newton - or abandoned their children - Einstein, Rousseau). Also, the male saints and many of the female saints remained childless. In many religions it is even believed that women cannot achieve any form of enlightenment because they have to deal with raising their children. In many areas and professions, children might be the reason that women do not advance to the same level as men. Or other interests might be more important (work, spirituality, art, hobbies, friends etc.) than raising a family, and they might indeed be mutually exclusive. Therefore, someone might simply not want children [28, 29]. Specifically after a certain age. Why does society impose the need to bear children on women who don't want [30] or need them when the world experiences over-population? This is very backward and fit only for orthodox countries. In a time when the state protects LGBT rights, society should equally have the right for women to remain childless.

\section{Rights of Childless Women}

Coercion or pressure to become a mother should be outlawed. Methods of planned parenthood should be further developed, and access should be facilitated. This is particularly important in the developing world, where at least for some women and in some countries, and apart from culture, also lack of means to plan parenthood are a cause for the high birth rates. This could also mean that for example female circumcision is a means to prevent more births, rather than a means to simple prevent sexual pleasure per se due to religious reasons. Furthermore, stigma should be fought the same way that stigma against the LGBT community is outlawed. A future world would include the human right for women to decide their own fate completely free of the traditional assumption that a woman has to become a mother. Other options for women's life plans should be promoted to a higher degree, citing notable examples of female pioneers from all walks of life, in the arts, in science, in business and politics, for example. Women should be encouraged to explore these options and encouraged in their ambitions (something that is still not traditionally pursued as intensively with women as it is with men).

\section{Conclusion}

All three major periods of war in history known to Western IR - the Greek wars 500BC, the 30 Years War and following troubles 1600AD, and the Two World Wars 1900 AD - were preceded by sudden massive population growth and produced major political inventions towards their resolution and the ensurance of peace.

With this assertion, this paper established a model of historical political evolution, different from existing models, but reliant one some of the important established data - IR scientists knowledge about major war and historical political works of importance - and some relatively unknown data to establish the causes spurring on these evolutionary changes the known and available data on global population growth throughout history are extremely sparse and probably based on estimates, but this is literally all science can possibly know.

Further research should investigate the reasons for such sudden unchecked population growth, how much population growth is reasonable and safe, as well as what history tells us about wars and their causes in other regions of the world where scientists know little. 


\section{Appendix}

Datasets

PopUlation Growth: $1,000,000$ B.C. TO 1990

\begin{tabular}{|c|c|c|c|}
\hline Year & Pop. (millions) & Growth rate & Comments \\
\hline$-1,000,000$ & 0.125 & 0.00000297 & \\
\hline$-300,000$ & 1 & 0.00000439 & \\
\hline$-25,000$ & 3.34 & 0.000031 & \\
\hline$-10,000$ & 4 & 0.000045 & \\
\hline-5000 & 5 & 0.000336 & \\
\hline-4000 & 7 & 0.000693 & \\
\hline-3000 & 14 & 0.000657 & \\
\hline-2000 & 27 & 0.000616 & \\
\hline-1000 & 50 & 0.001386 & \\
\hline-500 & 100 & 0.001352 & \\
\hline-200 & 150 & 0.000623 & \\
\hline 1 & 170 & 0.000559 & \\
\hline 200 & 190 & 0.0 & \\
\hline 400 & 190 & 0.000256 & \\
\hline 600 & 200 & 0.000477 & \\
\hline 800 & 220 & 0.000931 & \\
\hline 1000 & 265 & 0.001886 & \\
\hline 1100 & 320 & 0.001178 & \\
\hline 1200 & 360 & 0.0 & Mongol Invasions \\
\hline 1300 & 360 & -0.0002817 & Black Death \\
\hline 1400 & 350 & 0.0019420 & \\
\hline 1500 & 425 & 0.002487 & \\
\hline 1600 & 545 & 0.0 & 30 years war, Ming Collapse \\
\hline 1650 & 545 & 0.002253 & \\
\hline 1700 & 610 & 0.003316 & \\
\hline 1750 & 720 & 0.004463 & \\
\hline 1800 & 900 & 0.005754 & \\
\hline 1850 & 1200 & 0.003964 & \\
\hline 1875 & 1325 & 0.008164 & \\
\hline $\begin{array}{l}1900 \\
1920\end{array}$ & $\begin{array}{l}1625 \\
1813\end{array}$ & $\begin{array}{l}0.008306 \\
0.009164\end{array}$ & \\
\hline 1930 & 1987 & 0.010772 & \\
\hline 1940 & 2213 & 0.012832 & \\
\hline 1950 & 2516 & 0.018226 & \\
\hline 1960 & 3019 & 0.020151 & \\
\hline 1970 & 3693 & 0.018646 & \\
\hline 1980 & 4450 & 0.018101 & \\
\hline 1990 & 5333 & - & \\
\hline
\end{tabular}

The growth rate listed for period $t$ is the average growth rate from $t$ to $t+1$. Since differences of a constant at all times between different data sets would distort growth rates, the 25,000 to 10,000 B.c. growth rate is based on Deevey's population estimates, although the population estimate for 10,000 B.C. is from McEvedy and Jones. Similarly, the 1900-1920 krowth rate is based on the 1900-1925 average annual growth rate from McEvedy and Jones. Population figures from 1920 to 1940 and from 1950 to 1980 are from the 1952 and $1985 / 6$ editions of the United Nations Statistical Yearbook, respectively. The 1990 population estimate is from the 1991 World Almanac [1991], which attributes it to the U. S. Bureau of the Census.

Figure 3. The above figure illustrates the sudden, massive population increase around the time of the Greek wars (first circle in yellow), the 30 Years War (second circle in yellow), and the Two World Wars (third circle in yellow). This illustration shows quite clearly that the population growth rate was usually highest directly before major war. 


\begin{tabular}{|c|c|c|c|c|c|c|}
\hline Year & $\begin{array}{l}\text { Europe } \\
\text { population } \\
\text { (millions) }\end{array}$ & $\begin{array}{l}\text { Europe } \\
\text { growth } \\
\text { rate }(\%)\end{array}$ & $\begin{array}{l}\text { China } \\
\text { population } \\
\text { (millions) }\end{array}$ & $\begin{array}{l}\text { China } \\
\text { growth } \\
\text { rate }(\%)\end{array}$ & $\begin{array}{c}\text { India } \\
\text { population } \\
\text { (millions) }\end{array}$ & $\begin{array}{l}\text { India } \\
\text { growth } \\
\text { rate }(\%)\end{array}$ \\
\hline-200 & 26 & 0.0875 & 42 & 0.1157 & 31 & 0.0604 \\
\hline 1 & 31 & 0.0751 & 53 & 0.0869 & 35 & 0.0795 \\
\hline 200 & 36 & -0.0748 & 63 & -0.0864 & 41 & 0.0683 \\
\hline 400 & 31 & -0.0879 & 53 & -0.0291 & 47 & 0.0601 \\
\hline 600 & 26 & 0.0546 & 50 & 0.0000 & 53 & 0.0943 \\
\hline 800 & 29 & 0.1081 & 50 & 0.1388 & 64 & 0.1053 \\
\hline 1000 & 36 & 0.2007 & 66 & 0.4643 & 79 & 0.0494 \\
\hline 1100 & 44 & 0.2763 & 105 & 0.0910 & 83 & 0.0355 \\
\hline 1200 & 58 & 0.3090 & 115 & -0.2906 & 86 & 0.0565 \\
\hline 1300 & 79 & -0.2751 & 86 & -0.0599 & 91 & 0.0639 \\
\hline 1400 & 60 & 0.3001 & 81 & 0.3060 & 97 & 0.0792 \\
\hline 1500 & 81 & 0.2107 & 110 & 0.3747 & 105 & 0.2513 \\
\hline 1600 & 100 & 0.0976 & 160 & -0.2671 & 135 & 0.2107 \\
\hline 1650 & 105 & 0.2671 & 140 & 0.2671 & 150 & 0.1906 \\
\hline 1700 & 120 & 0.3083 & 160 & 0.6819 & 165 & 0.1177 \\
\hline 1750 & 140 & 0.5026 & 225 & 0.7660 & 175 & 0.1645 \\
\hline 1800 & 180 & 0.7735 & 330 & 0.5525 & 190 & 0.3821 \\
\hline 1850 & 265 & 0.6914 & 435 & -0.1883 & 230 & 0.4127 \\
\hline 1875 & 315 & 0.8543 & 415 & 0.5401 & 255 & 0.5145 \\
\hline 1900 & 390 & 0.7463 & 475 & 0.4382 & 290 & 0.5168 \\
\hline 1925 & 470 & 0.3657 & 530 & 0.4290 & 330 & 1.1959 \\
\hline 1950 & 515 & 0.8378 & 590 & 1.3892 & 445 & 2.2119 \\
\hline 1975 & 635 & - & 835 & - & 775 & - \\
\hline
\end{tabular}

Figure 4. The above figure shows, similar to the previous table, that the growth rate of population is usually very high directly before major war, declines in war, and then rises again. Compare the table the European growth rate to the dates around 1600 - however here, the growth pattern for 1600 itself is unusually low, which could mean the numbers are from the war period itself (in blue) - for the 30 Years War and 1875; and 1875 and 1900 following for the First World War respectively (circles in yellow). 
Europe, including European Russia: annual average rates of population increase per 1,000

Wi11cox

$\begin{array}{lccr}1931, & \text { Mombert } & \text { Durand } & \text { Clark } \\ 19401 & 1936 & 1967 & 1968\end{array}$

$\begin{array}{lcccc}1650-1750 & 3.4 & 2.4 & - & 3.7 \\ 1750-1800 & 5.9 & 4.0 & 4.4 & 5.7 \\ 1800-1850 & 6.9 & 4.6 & 6.1 & 8.62 \\ 1850-1900 & 8.2 & 8.2 & 7.8 & - \\ 1900-1950 & - & - & 5.4 & - \\ 1950-1970 & - & - & 9.6^{3} & -\end{array}$

Figure 5. In this figure, one sees the significant population increase in Europe before the First World War (circles in yellow).

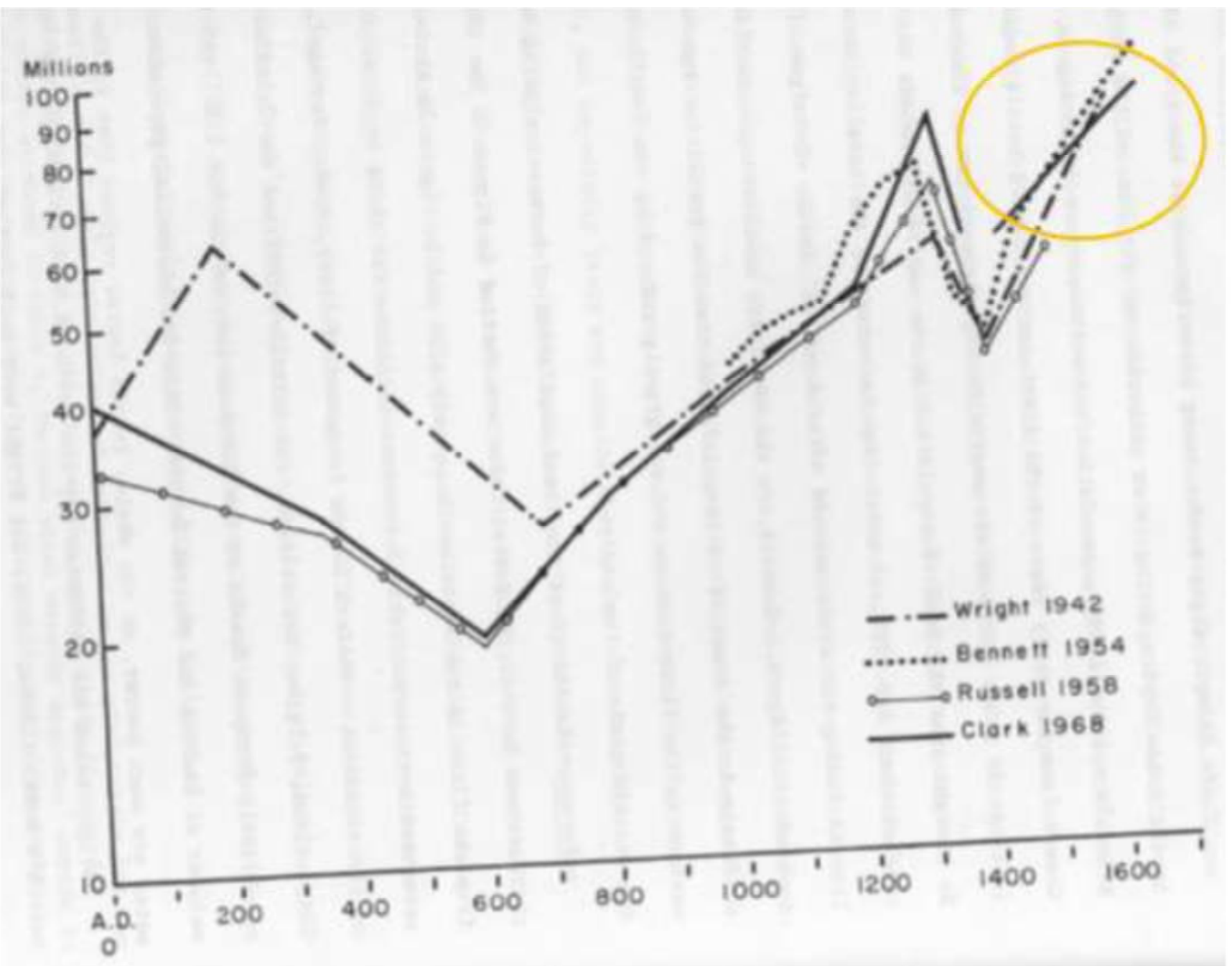

Figure 6. This figure shows that the period between $O A D$ and 1100 was a period that did not show as massive population increase. It is also believed to have been a period of relative calm in European history. The period when wars, including major wars, occurred again - the 30 Years War around the early $17^{\text {th }}$ century with the conclusion of the Treaty of Westphalia which established the principle of sovereignty in 1648 - is shown here as a period of rapid population increase above the levels ever experienced before to that date. 


\begin{tabular}{|c|c|c|c|c|c|c|}
\hline \multirow[b]{2}{*}{ Dates } & \multirow[b]{2}{*}{ Dynasties } & \multicolumn{3}{|c|}{ Recorded totals } & \multicolumn{2}{|c|}{ Adjusted totals, persons } \\
\hline & & Persons & $\begin{array}{l}\text { House- } \\
\text { holds }\end{array}$ & $\begin{array}{c}\text { Persons per } \\
\text { household }\end{array}$ & $\begin{array}{c}\text { A11 } \\
\text { areas }\end{array}$ & $\begin{array}{c}\text { Within China } \\
\text { Proper }\end{array}$ \\
\hline & & (n11) & 11ons) & & (m1 & \\
\hline A.D. 2 & Western Han & 59.6 & 12.2 & 4.9 & 74 & $b_{71}$ \\
\hline 88 & Eastern Han & 43.4 & 7.5 & 5.8 & 45 & $b_{43}$ \\
\hline 156 & Easterm Han & 56.5 & 10.7 & 5.5 & 64 & $b_{62}$ \\
\hline 606 & Su1 & 46.0 & 8.9 & 5.2 & 53 & 53 \\
\hline 705 & $T^{\prime}$ ang & 37.1 & 6.2 & 6.0 & 37 & 37 \\
\hline 755 & $T$ 'ang & 52.9 & 8.9 & 5.9 & 53 & 52 \\
\hline 1014 & Sung & 22.0 & 9.1 & 2.4 & 55 & 55 \\
\hline 1103 & Sung & 46.0 & 20.5 & 2.2 & 123 & 123 \\
\hline 1193-95 & Sung and Chin & c76. 3 & $c_{19.5}$ & - & $c_{121}$ & 121 \\
\hline 1290 & Yuan (Mongo1) & 58.8 & 13.2 & 4.5 & 86 & 86 \\
\hline 1393 & Ming & 60.5 & 10.6 & 5.7 & 61 & 61 \\
\hline 1751 & Ch'ing & 181.8 & - & - & 209 & $\mathrm{~d}_{206}$ \\
\hline 1774 & Ch'ing & 221.0 & - & - & 261 & $d_{260}$ \\
\hline 1775 & Ch'ing & 264.6 & - & - & 265 & $d_{264}$ \\
\hline 1805 & Ch'ing & 332.2 & - & - & 332 & $d_{331}$ \\
\hline 1851 & $\mathrm{Ch}^{\prime}$ ing & 431.9 & - & - & 432 & d 429 \\
\hline 1953 & People's Rep. & 582.6 & - & - & 583 & 518 \\
\hline
\end{tabular}

In terns of the 1953 census classification of areas, China Proper as defined for the purpose of this classification comprises Hope1, Shansi, Shensi, Kansu, Szechwan, Yunnan, and the provinces on the mainland to the south and east of these.

b

Not including Fukien and adjacent areas in southeastern China, which were outside the Han empire.

c

Sums of f1gures for southern China under the rule of the Sung and northern China under the rule of the Chin Dynasty, as follows:

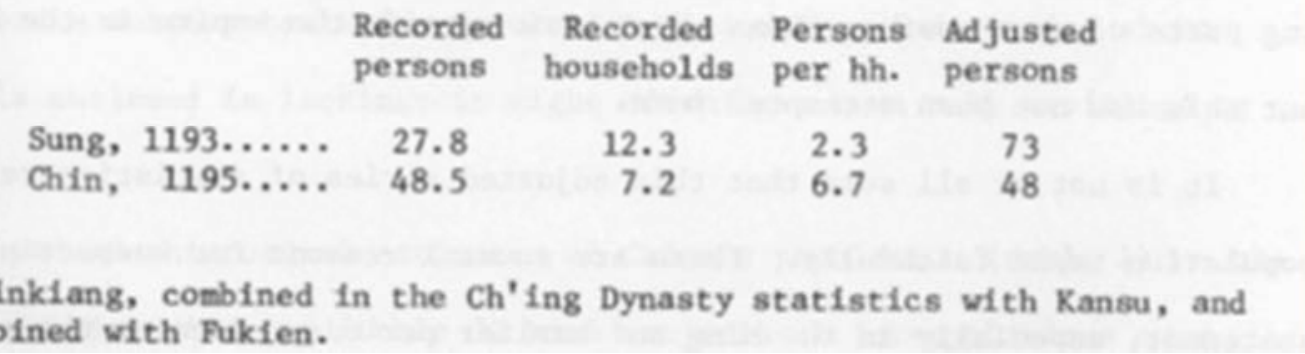

Figure 7. Chinese census or registration statistics, selected dates, AD 2-1953. The Ch'ing dynasty, in which there was massive population increase, was also a period of major war in Chinese history. 


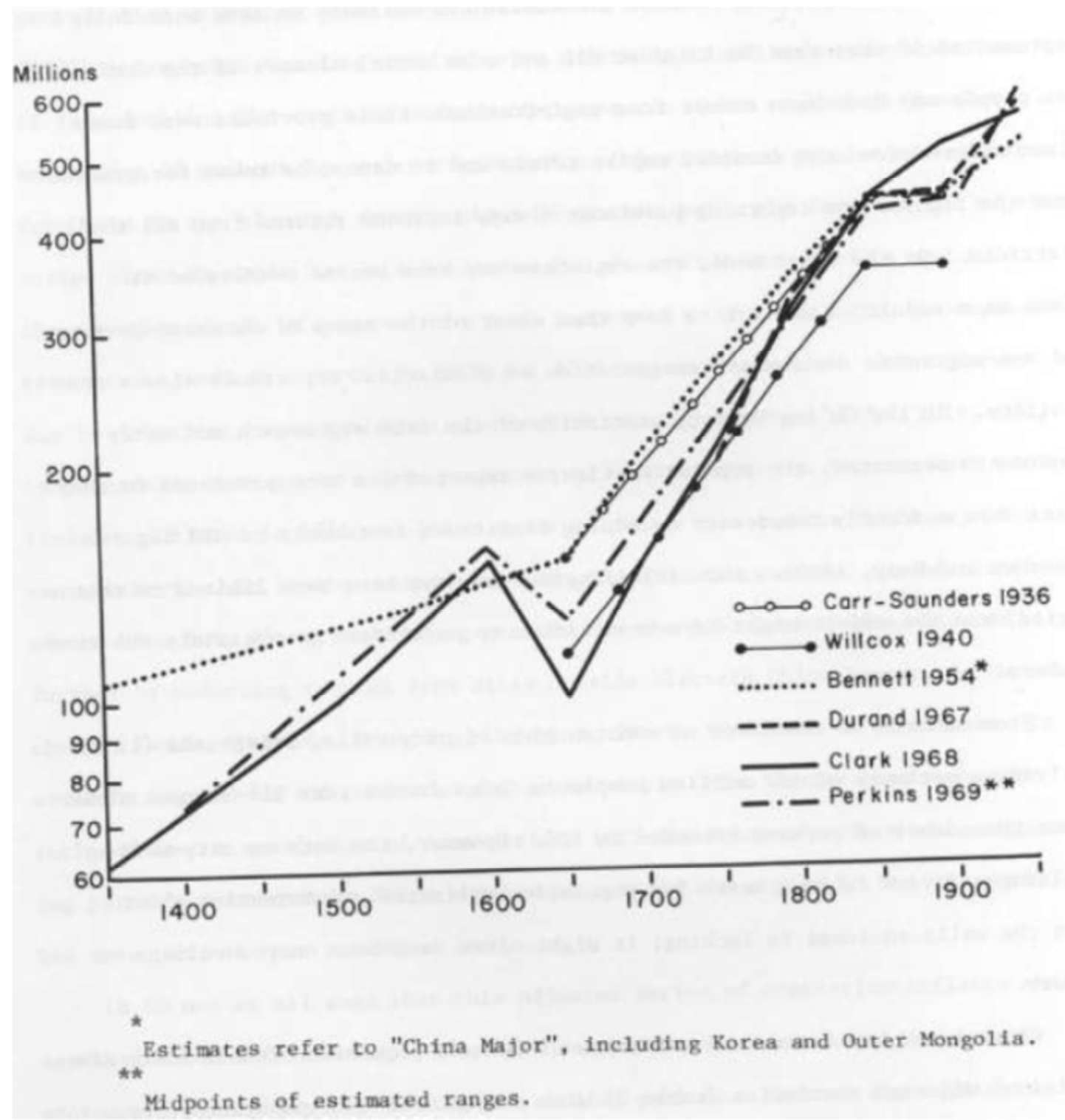

Figure 8. China: Population estimates since the fourteenth century AD. This figure shows periods of rapid population increase in Chinese history. These periods correspond to periods of major war in Chinese history, mainly since the Ch'ing dynasty since 1700.

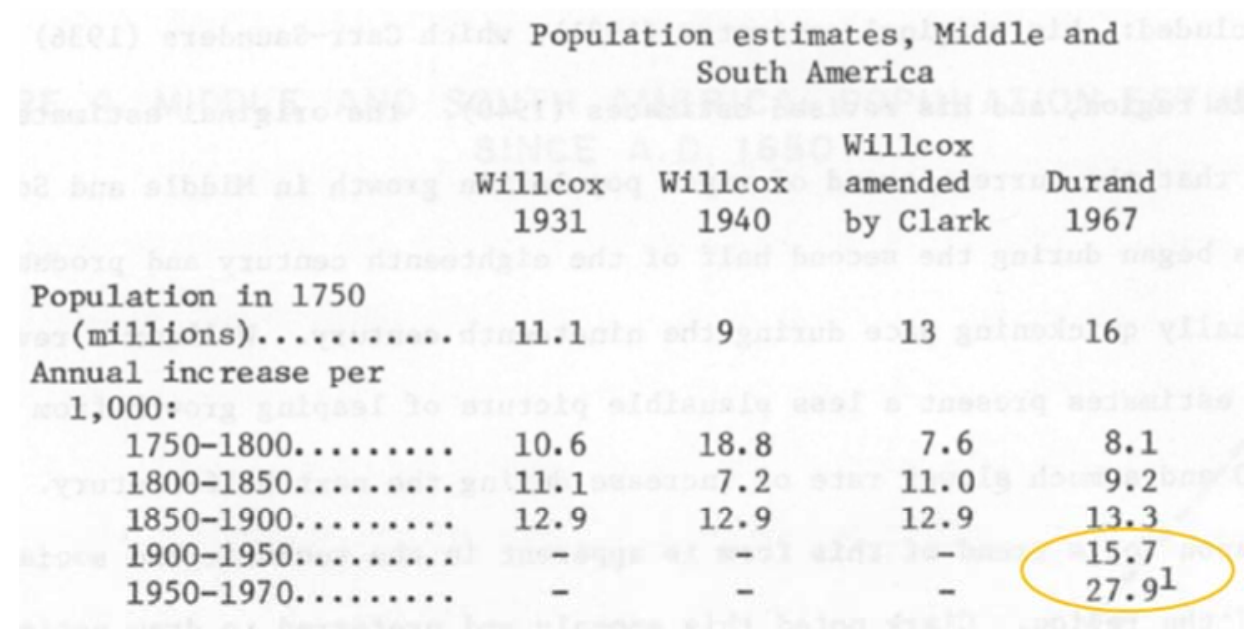

Figure 9. This figure can be correlated to the conflicts in South America that occurred in the 1960ies to 1980ies, after massive population increase around 1900 and following (yellow circle). 
Appendix sources:

Duran, J. D. (1974): Historical Estimates of World Population: An Evaluation. PSC Analytical and Technical Report Series No 9. Online: http://repository.upenn.edu/psc_penn_papers/9.

Kremer, M. (1993): Population Growth and Technological Change. One Million B. C. to 1990. The Quarterly Journal of Economics. Vol. 108, No. 3, 681-716.

\section{References}

[1] Malchow, H. (2016): History and International Relations. From the Ancient World to the $21^{\text {st }}$ Century. London: Bloomsbury: 107.

[2] Modelski, G. (1987): Long cycles in world politics. Berlin: Springer.

[3] Cashman, G. (2000): What Causes War? An Introduction to Theories of International Conflict. Lanham: Lexington Books.

[4] Durand, J. D. (1974): Historical Estimates of World Population: An Evaluation. PSC Analytical and Technical Report Series.

http://repository.upenn.edu/psc_penn_papers/9.

[5] Tang, S. (2013): The Social Evolution of International Politics. Oxford: Oxford University Press: 166.

[6] Tang, S. (2013): The Social Evolution of International Politics. Oxford: Oxford University Press: 114.

[7] Malchow, H. (2016): History and International Relations. From the Ancient World to the $21^{\text {st }}$ Century. London: Bloomsbury: 106.

[8] Zarnett, D. (2017): What does Realist foreign policy activism tell us about Realist Theory? Foreign Policy Analysis, 13, 618-637: 628 .

[9] Plato, in Hammond, R. M. (1951). Hammond, city-state and world-state in greek and roman political theory. The Classical Weekly, 45, 203. Retrieved from https://search.proquest.com/docview/1296315480?accountid= 11528: $18 \mathrm{ff}$

[10] Malchow, H. (2016): History and International Relations. From the Ancient World to the $21^{\text {st }}$ Century. London: Bloomsbury: Chapter 6; 168-170.

[11] Malchow, H. (2016): History and International Relations. From the Ancient World to the $21^{\text {st }}$ Century. London: Bloomsbury: 187-188.

[12] Malchow, H. (2016): History and International Relations. From the Ancient World to the $21^{\text {st }}$ Century. London: Bloomsbury: 186.

[13] Waltz, K. (1979): Theory of International Politics. New York: WW Norton.

[14] Mearsheiemer, J. (2001): The Tragedy of Great Power
Politics. New York: WW Norton.

[15] Cashman, G. (1993): What Causes War? An Introduction to the Theories of International Conflict. Lanham: Rowman \& Littlefield.

[16] Beyer, A. C. (2016): Inequality and Violence: A Re-appraisal of Man, the State and War. London: Routledge.

[17] Huntington, S. (1996): The Clash of Civilisations and the Remaking of World Order. New York: Simon and Schuster.

[18] Beyer, A. C. (2016): Inequality and Violence: A Re-appraisal of Man, the State and War. London: Routledge.

[19] Beyer, A. C. (2016): Violent Globalisms: Conflict in Response to Empire. London: Routledge.

[20] Penrose, E. F. (1934): Population Theories and Their Application with special reference to Japan. Stanford: Stanford University Press: 329f.

[21] Nassef, A. (1976): Problems of Maintaining Employment in Developing Countries in the Face of Rapid Population Growth. New York: Macmillan; 394-410: 394-410; Visaria, P. (1976): The Importance of Labour-force Structure in Relation to Employment and Unemployment in Less-developed Countries. New York: Macmillan; 411-438: 411-438.

[22] Lee, J. Z. and F. Wang (2000): Population, overty, and Subsistence in China, 1700-2000. In: Bengtsson, T. and O. Saito (eds.): Population and Economy: From Hunger to Modern Economic Growth. Oxford: Oxford University Press; 73-110: $74 \mathrm{f}$

[23] Kuznets, S. (1998): Population Trends and Modern Economic Growth. In: Demeny, P. and

[24] G. McNicoll (eds.): The Earthscan Reader in Population and Development. London: Earthscan; 5-18: 7f.

[25] Blanchet, D. (1998): Relationships between Population Growth and Economic Growth. In: Demeny, P. and G. McNicoll (eds.): The Earthscan Reader in Population and Development. London: Earthscan; 19-27: 19.

[26] Belkin, L (2011): Do Gen X Women Choose Work Over Kids? Online: https://parenting.blogs.nytimes.com/2011/06/30/gen-xwomen-choose-work-over-kids/.

[27] Smith, D. (2013): The State of the World Atlas. Oxford: New Internationalist.

[28] Gillespie, R (2000): When no means no: Disbelief, disregard and deviance as discourses of voluntary childlessness. In Women's Studies International Forum, 23:2, 223 - 234.

[29] Pergamon, A and JE Veevers (1979): Voluntary childlessness: A review of issues and evidence. Marriage \& Family Review, $2: 2,1-26$.

[30] Kelly, M (2009): Women's Voluntary Childlessness. Radical Rejection of Motherhood? WSQ: Women's Studies Quarterly, Volume 37, Numbers 3 \& 4, Fall/Winter 2009, pp. 157-172. 